\title{
Results of a hospitalization policy of asymptomatic and pre-symptomatic COVID-19-positive long-term care facility residents in the province of Salzburg - a report from the AGMT COVID-19 Registry
}

\author{
Florian Huemer • Gabriel Rinnerthaler • Benedikt Jörg • Patrick Morre • \\ Birgit Stegbuchner • Elisabeth Proksch • Stefanie Fleimisch • Hannes Oberkofler • \\ Iris Kremser • Richard Greil • Alexander Egle
}

Received: 19 December 2020 / Accepted: 8 March 2021 / Published online: 10 April 2021

(C) The Author(s) 2021

\begin{abstract}
COVID-19-associated case fatality rates up to $48 \%$ were reported among nursing facility residents. During the first wave of the COVID-19 pandemic, routine SARS-CoV-2 testing in long-term care facilities in the Province of Salzburg and centralized hospitalization in the COVID-19 unit of the Paracelsus Medical University Salzburg (Austria) irrespective of symptoms was implemented. Baseline characteristics and the course of COVID-19 disease were assessed among hospitalized long-term care facility residents within the COVID-19 Registry of the Austrian Group Medical
\end{abstract}

Florian Huemer and Gabriel Rinnerthaler contributed equally to this work.

$\underline{\text { Richard Greil and Alexander Egle contributed equally to this work. }}$

F. Huemer · G. Rinnerthaler · B. Jörg · P. Morre •

R. Greil $(\bowtie) \cdot$ A. Egle

Department of Internal Medicine III with Haematology, Medical Oncology, Haemostaseology, Infectiology and Rheumatology, Oncologic Center, Salzburg Cancer Research Institute - Laboratory for Immunological and Molecular Cancer Research (SCRI-LIMCR), Paracelsus Medical University Salzburg, 5020 Salzburg, Austria

e-mail:r.greil@me.com

G. Rinnerthaler · R. Greil · A. Egle

Cancer Cluster Salzburg, 5020 Salzburg, Austria

B. Stegbuchner $\cdot$ E. Proksch

Department of Geriatric Medicine, Christian-Doppler-Klinik,

Paracelsus Medical University Salzburg, 5020 Salzburg, Austria
Tumor Therapy (AGMT; NCT04351529). Between the $24^{\text {th }}$ of March and the $20^{\text {th }}$ of April 2020, 50 COVID-19-positive residents were hospitalized. The median age was 84.5 years (range: $79-88$ ) and the median number of comorbidities and baseline medication classes was 6 (IQR: 4-7) and 5 (IQR: 3-6), respectively. At admission, 31 residents (62\%) were symptomatic, nine residents $(18 \%)$ pre-symptomatic whereas ten residents $(20 \%)$ remained asymptomatic. The 30 day mortality rate from hospitalization was $32 \%$ and significantly higher in symptomatic residents at

\author{
S. Fleimisch \\ Department of Pneumology, Paracelsus Medical University \\ Salzburg, 5020 Salzburg, Austria \\ H. Oberkofler · I. Kremser \\ Department of Laboratory Medicine, Paracelsus Medical University \\ Salzburg, 5020 Salzburg, Austria \\ R. Greil \\ AGMT, 5020 Salzburg, Austria
}


admission when compared to asymptomatic residents including pre-symptomatic residents $(48 \%$ [95\% CI: $27-63 \%$ ] versus 5\% [95\% CI: $0-15 \%], p=0.006)$. The Early Warning Score (EWS) at admission was associated with 30-day mortality: high risk: $100 \%$, intermediate risk: $50 \%$ (95\% CI: $0-78 \%$ ), and low risk: $21 \%(95 \%$ CI: $7-32 \%)(p<0.001)$. In light of comparably low mortality rates between asymptomatic and pre-symptomatic hospitalized COVID-19-positive residents, we suggest the supply of comparable intensity and quality of monitoring and care in long-term care facilities as an alternative to immediate hospitalization upon a positive COVID-19 test in asymptomatic residents.

Keywords SARS-CoV-2 - Pandemic · COVID-19 . Long-term care facility $\cdot$ Nursing facility $\cdot$ Residents

\section{Introduction}

Coronavirus disease 2019 (COVID-19) is an infectious disease caused by severe acute respiratory syndrome coronavirus 2 (SARS-CoV-2). The disease was first identified at the end of 2019 in Wuhan, the capital of Hubei province in central China, and has since spread globally [1]. COVID-19 leads to high morbidity and mortality, mainly in elderly and comorbid populations [2], but late-sequelae may additionally burden younger patients, including previously healthy people. COVID19 outbreaks in residential homes as well as in shortand long-term care facilities represent a considerable threat with hospitalization rates ranging from $4 \%$ in the UK [3] to $19 \%$ in the USA [4]. With case fatality rates up to $48 \%$ [3-6], reported COVID-19-associated deaths in nursing facilities have been unacceptably high. It is noteworthy that in some countries, COVID-19associated deaths were not counted if death occurred outside the hospital (including long-term care facilities) [7]; therefore, death rates in long-term-care facilities might be underrecognized and underestimated. The Center for Disease Control and Prevention (CDC) updates its recommendations for COVID-19 infection prevention and control in nursing facilities [8] on a regular basis aiming at preventing the spread and protecting residents as well as health care workers from severe infection, hospitalization, and death. Similar to many other regions, long-term care facilities were ill-prepared for such a pandemic crisis. They were short of place for single person isolation, suffered training for use of personal protective equipment (PPE), which they were dramatically short of, and did not have granted regular, continuous, and acute care by practitioners trained for this situation. As a result, our policy was to hospitalize symptomatic as well as asymptomatic COVID-19 positive long-term care facility residents in the COVID-19 unit of the Paracelsus Medical University Salzburg (Austria) in order to allow infection control in sometimes very large residencies as well as to take over treatment of many very difficult to care for patients with substantial morbidities including neuropsychiatric symptoms or behavioral alterations. Despite the rollout of various COVID-19 vaccines [9-11], the implementation of vaccination strategies and prioritization of high-risk groups and health care personnel, factors such as e.g. shortness of supply and the occurrence of SARSCoV-2 variants [12-14], could pose a considerable challenge to pandemic control in long-term care facilities. Also, very elderly and comorbid populations similar to long-term care residents were severely underrepresented in vaccine trials. Efficacy data may be very different in such a population and it is likely that it may be significantly lower.

In this single-center study, we aimed at studying the course of COVID-19 and clinical outcome in symptomatic and asymptomatic hospitalized long-term care facility residents in the province of Salzburg (Austria) included in the COVID-19 Registry of the Austrian Group Medical Tumor Therapy (AGMT, NCT04351529).

\section{Patients and methods}

Patients

In this observational analysis, we included unselected consecutively hospitalized residents of long-term care facilities (including nursing homes and facilities for mentally and/or physically handicapped people) that had been tested COVID-19 positive by RT-PCR from a nasopharyngeal swab. All included patients alive at the date of analysis gave their informed consent to participate in the AGMT COVID-19 Registry (NCT04351529), which has been documented in the respective medical chart. Due to the non-interventional nature of the AGMT COVID-19 Registry, only routine data, which have already been recorded in the patients' medical charts, were analyzed. Symptoms during the preceding 14 days were assessed on an interview and review of medical records basis. 
Treatment indication, the decision to offer treatment, treatment choice, dose, schedule, and dose reductions/ escalations were exclusively based on the risk/benefit estimation of the treating physician.

\section{RT-PCR}

In the COVID-19 unit, RT-PCR tests (Altona Diagnostics, Germany) for SARS-CoV-2 were routinely performed from nasopharyngeal swabs.

\section{Discharge policy}

Relief of COVID-19 associated symptoms for at least $48 \mathrm{~h}$ and two serial negative RT-PCR tests with a minimum interval of $24 \mathrm{~h}$ was a prerequisite for discharge from the COVID-19 unit. When the Austrian health ministry (paralleling the German Robert-Koch Institute [15]) issued new guidance allowing to use a quantitative marker ( $\mathrm{Ct}$ above 30 ) to exclude infectious risk, the latter discharge policy was adopted.

\section{Early Warning Score}

The Early Warning Score (EWS) incorporating respiratory rate, oxygen saturation, demand for oxygen supply, body temperature, systolic blood pressure, heart rate, and level of consciousness was applied for standard assessment of acute illness severity. A higher score reflects a more severe acute illness with EWS 0-4, EWS 5-6, and EWS $\geq 7$ classified as low, intermediate, and high score, respectively (Supplementary Table 1) [16]. The frequency of assessment as well as the respective measures was based on the discretion of the treating physician.

\section{Patient categorization}

Residents were classified as symptomatic if they had typical symptoms of a respiratory infection (with or without fever) such as cough, sore throat, shortness of breath, or atypical symptoms such as diarrhea, headache, fatigue, chills, myalgia, painful joints, or deterioration of confusion at the time point of admission to the COVID-19 unit. Residents without symptoms at admission to the COVID-19 unit, who developed typical or atypical symptoms during the course of disease, were classified as pre-symptomatic. Asymptomatic patients did never experience typical or atypical symptoms during medical care in the COVID-19 unit.

Monitoring and treatment

Fluid balance charts, laboratory tests, blood gas analyses, and imaging studies were ordered on an individual basis. Medical supportive treatment was initiated at the discretion of the treating physician and mainly consisted of oxygen supply, administration of antibiotics, intravenous (iv) hydration, enteral and/or parenteral nutrition support, and physical and respiratory therapy. Low-molecularweight heparin-based prophylactic anticoagulation therapy was temporarily established in each resident without pre-existing anticoagulation therapy. Access to treatment with the anti-interleukin-6 (IL-6) receptor blocking monoclonal antibody tocilizumab (400 $\mathrm{mg}$ iv up to two applications in total) was made available by Roche ${ }^{\circledR}$ explicitly for off-label use. The decision to apply tocilizumab was based on the oxygen demand and inflammation parameters on an individual basis. Remdesivir, dexamethasone, and convalescent plasma transfusions were not regularly applied during this study period.

Statistical analyses

Differences in patient baseline characteristics between two groups (symptomatic versus asymptomatic; survivors versus non-survivors) were tested by Pearson's $\chi^{2}$-test. For continuous data, the difference between the two groups was calculated with two-sided Wilcoxon rank-sum test. In an exploratory analysis, we used the Kaplan-Meier method for survival curves and to evaluate OS differences according to baseline characteristics. Log-rank test was used to compare survival distributions between two patient groups. A Fine-Gray regression model was used for competing risk analysis (death versus discharge). All analyses were performed using the statistical software environment R (version 3.5.1) including package "survival."

\section{Results}

During the first wave between March 2020 and April 2020, 50 residents from twelve long-term care facilities were tested COVID-19 positive by RT-PCR from nasopharyngeal swabs and hospitalized in the COVID-19 unit of the Paracelsus Medical University Salzburg (Austria) irrespective of symptoms. The median age of 
Table 1 Baseline characteristics, clinical symptoms, and comorbidities among 50 long-term care facility residents admitted to the COVID19 unit who were hospitalized due to symptomatic or asymptomatic COVID-19 infection

\begin{tabular}{|c|c|c|c|c|}
\hline & Total $(n=50)$ & Symptomatic $(n=31,62 \%)$ & Asymptomatic $(n=19,38 \%)$ & $p$ value \\
\hline Age (median, IQR) & $\begin{array}{l}84.5 \\
(79-88)\end{array}$ & $\begin{array}{l}85 \\
(79-87)\end{array}$ & $\begin{array}{l}84 \\
(76.5-89.5)\end{array}$ & $0.834 *$ \\
\hline Sex & & & & 0.500 \\
\hline Female & $34(68)$ & $20(65)$ & $14(74)$ & \\
\hline Male & $16(32)$ & $11(35)$ & $5(26)$ & \\
\hline EWS at admission (median, IQR) & $\begin{array}{l}3 \\
(1-4)\end{array}$ & $\begin{array}{l}3 \\
(3-5)\end{array}$ & $\begin{array}{l}1 \\
(0-2)\end{array}$ & $<0.001 *$ \\
\hline New or increased oxygen demand at admission & & & & 0.006 \\
\hline No & $30(60)$ & $14(45)$ & $16(84)$ & \\
\hline Yes & $20(40)$ & $17(55)$ & $3(16)$ & \\
\hline \multicolumn{5}{|l|}{ New or increased oxygen demand at COVID-19 unit } \\
\hline No & $18(37)$ & $7(23)$ & $11(61)$ & 0.012 \\
\hline Yes & $31(63)$ & $24(77)$ & $7(39)$ & \\
\hline Unknown & 1 & 0 & 1 & \\
\hline ICU transfer & & & & 0.721 \\
\hline No & $48(96)$ & $30(97)$ & $18(95)$ & \\
\hline Yes & $2(4)$ & $1(3)$ & $1(5)$ & \\
\hline \multicolumn{5}{|l|}{ Clinical symptoms at admission } \\
\hline \multicolumn{5}{|l|}{ Fever $\left(>37 \cdot 5^{\circ} \mathrm{C}\right)$} \\
\hline No & & $11(35)$ & & \\
\hline Yes & & $20(65)$ & & \\
\hline \multicolumn{5}{|l|}{ Dyspnea } \\
\hline No & & $15(48)$ & & \\
\hline Yes & & $16(52)$ & & \\
\hline \multicolumn{5}{|l|}{ Cough } \\
\hline No & & $15(48)$ & & \\
\hline Yes & & $16(52)$ & & \\
\hline \multicolumn{5}{|l|}{ Headache } \\
\hline No & & $31(100)$ & & \\
\hline Yes & & $0(0)$ & & \\
\hline \multicolumn{5}{|l|}{ Chills } \\
\hline No & & $30(97)$ & & \\
\hline Yes & & $1(3)$ & & \\
\hline \multicolumn{5}{|l|}{ Sore throat } \\
\hline No & & $30(100)$ & & \\
\hline Yes & & $0(0)$ & & \\
\hline Missing & & 1 & & \\
\hline \multicolumn{5}{|l|}{ Rhinorrhea } \\
\hline No & & $31(100)$ & & \\
\hline Yes & & $0(0)$ & & \\
\hline \multicolumn{5}{|l|}{ Diarrhea } \\
\hline No & & $30(97)$ & & \\
\hline Yes & & $1(3)$ & & \\
\hline
\end{tabular}


Table 1 (continued)

Total $(n=50) \quad$ Symptomatic $(n=31,62 \%) \quad$ Asymptomatic $(n=19,38 \%)$

$p$ value

\section{Fatigue}

No

Yes

Myalgia/painful joints

No

Yes

Deteriorated confusion

No

Yes

Comorbidities

Number of comorbidities

Chronic lung disease

No

Yes

Cardiac disease ${ }^{\#}$

No

Yes

Hypertension

No

Yes

Diabetes mellitus type 2

No

Yes

Cerebrovascular disease

No

Yes

Vascular disease

No

Yes

Chronic kidney disease

No

Yes

Neurodegenerative disease

No

Yes

Unknown

Cognitive impairment

No

Yes

Unknown

Active hematologic disease

No

Yes
$18(58)$

13 (42)

30 (97)

1 (3)

24 (77)

$7(23)$

6

5

(4-7)

(4-7)

$44(88) \quad 27(87)$

6 (12)

4 (13)

22 (44) $15(48)$

$28(56) \quad 16(52)$

7 (14) $6(19)$

$25(81)$

43 (86)

$34(68) \quad 22(71)$

9 (29)

$36(72) \quad 21(68)$

$14(28) \quad 10(32)$

$45(90) \quad 29(94)$

2 (6)

5 (10)

$17(55)$

14 (45)

24 (48)

38 (78)

22 (73)

$11(22)$

8 (27)

1

6 (12) $2(7)$

42 (88) $27(93)$

22

49 (98) $\quad 30(97)$

$1(2) \quad 1(3)$
6

(5-7)

17 (90)

2 (10)

0.163

0.566

0.392

$16(84)$

0.285

0.182

$19(100)$

0.179

0.802

7 (37)

$1(5)$

$12(63)$

7 (37)

15 (79)

$4(21)$

3 (16)

9 (47)

$10(53)$

$16(84)$

3 (16)

0

4 (21)

15 (79)

0

$0(0)$
0.491

0.608 
Table 1 (continued)

\begin{tabular}{|c|c|c|c|c|}
\hline & Total $(n=50)$ & Symptomatic $(n=31,62 \%)$ & Asymptomatic $(n=19,38 \%)$ & $p$ value \\
\hline Active oncologic disease & & & & 0.606 \\
\hline No & $46(92)$ & $29(94)$ & $17(90)$ & \\
\hline Yes & $4(8)$ & $2(6)$ & $2(10)$ & \\
\hline Thyroid disorder & & & & 0.968 \\
\hline No & $37(74)$ & $23(74)$ & $14(74)$ & \\
\hline Yes & $13(26)$ & $8(26)$ & $5(26)$ & \\
\hline History of thromboembolic events & & & & 0.660 \\
\hline No & $41(82)$ & $26(84)$ & $15(79)$ & \\
\hline Yes & $9(18)$ & $5(16)$ & $4(21)$ & \\
\hline Autoimmune disease & & & & NA \\
\hline No & $50(100)$ & $31(100)$ & $19(100)$ & \\
\hline Yes & $0(0)$ & $0(0)$ & $0(0)$ & \\
\hline
\end{tabular}

*Wilcoxon rank-sum test

\# Coronary heart disease, chronic heart failure, arrhythmia, and/or heart valve disease

$I C U$, intensive care unit; NA, not available; EWS, Early Warning Score

the entire cohort was 84.5 years and with a female $(68 \%)$ to male $(32 \%)$ preponderance (Table 1$)$.

\section{Clinical symptoms}

While COVID-19 testing was initially performed due to symptoms in 28 residents (56\%), 22 residents (44\%) were asymptomatic during SARS-CoV-2 screening tests in the long-term care facilities. At admission to the COVID-19 unit, 31 residents $(62 \%)$ presented with typical or atypical symptoms and were classified "symptomatic." Ten residents (20\%) remained asymptomatic during the entire hospital stay whereas nine residents (18\%) developed symptoms during the course of disease, classified as "pre-symptomatic." Among symptomatic residents, 29 (94\%) displayed typical COVID19 symptoms whereas only two patients $(6 \%)$ presented with atypical symptoms at admission.

\section{Comorbidities}

Pre-existing comorbidities were present in the majority of residents with cognitive impairment $(88 \%)$, hypertension $(86 \%)$, cardiac disease including coronary heart disease, chronic heart failure, arrhythmia and/or heart valve disease (56\%), chronic kidney disease $(48 \%)$, and diabetes mellitus type II (32\%) ranking among the leading comorbidities. The distribution of comorbidities did not statistically significantly differ between symptomatic and asymptomatic residents at admission. The median number of pre-existing comorbidities was 6 (IQR: 4-7) (Table 1).

Co-medication

Psychopharmacologic drugs (68\%), ACE inhibitors (30\%), angiotensin receptor blockers (ARBs, 20\%), and other antihypertensive agents (66\%), proton pump inhibitors $(52 \%)$, therapeutic anticoagulation therapy $(34 \%)$, opiates $(32 \%)$, and platelet aggregation inhibitors $(26 \%)$ were the most frequently reported comedication classes. Statistically significant differences of pre-existing co-medication were found between symptomatic and asymptomatic residents at admission to the COVID-19 unit: ACE inhibitors (19\% versus $47 \%, p=0.036$ ), ARBs (29\% versus $5 \%, p=0.041)$, antibiotics $(19 \%$ versus $0 \%, p=0.041)$, and opiates $(19 \%$ versus $53 \%, p=0.014)$. The median number of baseline medication classes was 5 (IQR: 3-6) (Table 2).

\section{Baseline laboratory values}

Symptomatic residents at admission showed significantly higher baseline levels of ferritin ( 537 versus $226 \mathrm{mcg} /$ $1, p=0.019$ ), D-dimer ( 1.79 versus $0.73 \mathrm{mg} / \mathrm{l}, p=0.015$ ), blood urea nitrogen $(\mathrm{BUN}, 52$ versus $41 \mathrm{mg} / \mathrm{dl}$, $p=0.032)$, and hemoglobin (12.7 versus $11.6 \mathrm{~g} / \mathrm{dl}$, $p=0.039)$ when compared to asymptomatic residents (Table 2). 
Table 2 Co-medication and laboratory values of 50 long-term care facility residents hospitalized due to symptomatic or asymptomatic COVID-19 infection

Total $(n=50) \quad$ Symptomatic $(n=31,62 \%) \quad$ Asymptomatic $(n=19,38 \%) \quad p$ value

Co-medication at admission

Number of medication classes

5

(3-6)

4

(3-6)

ACE inhibitor

No

Yes

ARBs

No

Yes

Other antihypertensive therapy

$$
\text { No }
$$

Yes

Antibiotics

No

Yes

Proton pump inhibitors

No

Yes

Statins

No

Yes

NSAIDs

No

Yes

Opiates

No

Yes

Long-term systemic steroid therapy

( $\geq 14$ days)

No

Yes

Short-term systemic steroid therapy

$(<14$ days $)$

No

Yes

Inhaled steroid therapy

No

Yes

Antidiabetic therapy (excluding insulin)

No

Yes

Insulin therapy

No

Yes
$35(70)$

$15(30)$

$25(81)$

6 (19)

$40(80)$

$10(20)$

$22(71)$

9 (29)

17 (34)

13 (42)

18 (58)

33 (66)

$44(88)$

6 (12)

25 (81)

6 (19)

24 (48)

15 (48)

$16(52)$

26 (52)

38 (76)

12 (24)

22 (71)

9 (29)

44 (88)

6 (12)

29 (94)

2 (6)

34 (68)

$16(32)$

25 (81)

6 (19)

49 (98)

1 (2)

31 (100)

0 (0)

49 (98)

1 (2)

30 (97)

1 (3)

47 (94)

3 (6)

28 (90)

3 (10)

43 (86)

$26(84)$

5 (16)

44 (88)

$28(90)$

3 (10)

6 (12)
7 (14)
$8(95)$

1 (5)

5

(4-6)

10 (53)

9 (47)

18 (95)

1 (5)

4 (21)

15 (79)

19 (100)

0 (0)

9 (47)

10 (53)

$16(84)$

3 (16)

15 (79)

4 (21)

9 (47)

10 (53)

$0.255^{*}$

0.036

0.041

0.130

0.041

0.944

0.287

0.014

19 (100)

0 (0)

19 (100)

0 (0)

0.579

17 (90)

2 (10)

0.519

$16(84)$

3 (16) 
Table 2 (continued)

\begin{tabular}{|c|c|c|c|c|}
\hline & Total $(n=50)$ & Symptomatic $(n=31,62 \%)$ & Asymptomatic $(n=19,38 \%)$ & $p$ value \\
\hline Psychopharmacologic therapy & & & & 0.500 \\
\hline No & $16(32)$ & $11(35)$ & $5(26)$ & \\
\hline Yes & $34(68)$ & $20(65)$ & $14(74)$ & \\
\hline $\begin{array}{l}\text { Anticoagulation therapy } \\
\text { (therapeutic dose) })^{\S}\end{array}$ & & & & 0.344 \\
\hline No & $33(66)$ & $22(71)$ & $11(58)$ & \\
\hline Yes & $17(34)$ & $9(29)$ & $8(42)$ & \\
\hline Antiplatelet therapy & & & & 0.481 \\
\hline No & $37(74)$ & $24(77)$ & $13(68)$ & \\
\hline Yes & $13(26)$ & $7(23)$ & $6(32)$ & \\
\hline \multicolumn{5}{|l|}{ Laboratory values (IQR) } \\
\hline CRP (mg/dl) & $\begin{array}{l}4.8 \\
(1.5-12.0)\end{array}$ & $\begin{array}{l}4.6 \\
(1.9-10.3)\end{array}$ & $\begin{array}{l}5.2 \\
(1.35-13.7)\end{array}$ & $0.764 *$ \\
\hline Peak CRP (mg/dl) & $\begin{array}{l}10.1 \\
(4.4-16.3)\end{array}$ & $\begin{array}{l}9.8 \\
(4.5-15.6)\end{array}$ & $\begin{array}{l}12.2 \\
(4.4-17.2)\end{array}$ & $0.849 *$ \\
\hline IL-6 (pg/ml) & $\begin{array}{l}36.9 \\
(20.8-102)\end{array}$ & $\begin{array}{l}37.5 \\
(20.9-100.3)\end{array}$ & $\begin{array}{l}36.9 \\
(17-96.4)\end{array}$ & $0.774 *$ \\
\hline Peak IL-6 (pg/ml) & $\begin{array}{l}72.9 \\
(33.1-231)\end{array}$ & $\begin{array}{l}81.7 \\
(35-206.8)\end{array}$ & $\begin{array}{l}72.9 \\
(34.3-258)\end{array}$ & $0.975^{*}$ \\
\hline Ferritin (mcg/l) & $\begin{array}{l}426.5 \\
(196-910)\end{array}$ & $\begin{array}{l}537 \\
(324.5-1150)\end{array}$ & $\begin{array}{l}226 \\
(149.5-453.5)\end{array}$ & $0.019 *$ \\
\hline Peak ferritin (mcg/l) & $\begin{array}{l}540.5 \\
(300.5-1323)\end{array}$ & $\begin{array}{l}890 \\
(430.5-1610)\end{array}$ & $\begin{array}{l}398 \\
(236-672.5)\end{array}$ & $0.009 *$ \\
\hline Procalcitonin (mcg/l) & $\begin{array}{l}0.1 \\
(0.1-0.2)\end{array}$ & $\begin{array}{l}0.1 \\
(0.1-0.3)\end{array}$ & $\begin{array}{l}0.1 \\
(0.1-0.2)\end{array}$ & $0.262 *$ \\
\hline Peak procalcitonin $(\mathrm{mcg} / \mathrm{l})$ & $\begin{array}{l}0.2 \\
(0.1-0.5)\end{array}$ & $\begin{array}{l}0.3 \\
(0.1-0.5)\end{array}$ & $\begin{array}{l}0.2 \\
(0.1-0.5)\end{array}$ & $0.578^{*}$ \\
\hline ATIII $(\%)$ & $\begin{array}{l}87 \\
(77-100)\end{array}$ & $\begin{array}{l}90 \\
(79-101)\end{array}$ & $\begin{array}{l}83 \\
(75.5-96.5)\end{array}$ & $0.448 *$ \\
\hline D-dimer (mg/l) & $\begin{array}{l}1.02 \\
(0.65-2.80)\end{array}$ & $\begin{array}{l}1.79 \\
(0.82-3.65)\end{array}$ & $\begin{array}{l}0.73 \\
(0.57-1.16)\end{array}$ & $0.015^{*}$ \\
\hline Fibrinogen (mg/dl) & $\begin{array}{l}443 \\
(346-483)\end{array}$ & $\begin{array}{l}443 \\
(375.5-479.5)\end{array}$ & $\begin{array}{l}431 \\
(338-476)\end{array}$ & $0.644 *$ \\
\hline Prothrombin time $(\%)$ & $\begin{array}{l}75 \\
(68-88)\end{array}$ & $\begin{array}{l}76.5 \\
(66.5-89)\end{array}$ & $\begin{array}{l}75 \\
(68.5-82.5)\end{array}$ & $0.805^{*}$ \\
\hline PTT (s) & $\begin{array}{l}35 \\
(31-38)\end{array}$ & $\begin{array}{l}35 \\
(31-39.5)\end{array}$ & $\begin{array}{l}34 \\
(31.5-36)\end{array}$ & $0.673 *$ \\
\hline LDH (U/l) & $\begin{array}{l}279 \\
(209.5-312)\end{array}$ & $\begin{array}{l}281 \\
(218-329)\end{array}$ & $\begin{array}{l}267 \\
(209.5-302)\end{array}$ & $0.413 *$ \\
\hline Hs troponin $\mathrm{T}$ (ng/l) & $\begin{array}{l}36 \\
(24-49)\end{array}$ & $\begin{array}{l}40.5 \\
(34-65)\end{array}$ & $\begin{array}{l}28 \\
(22-44.5)\end{array}$ & $0.149 *$ \\
\hline Creatine kinase (U/l) & $\begin{array}{l}70 \\
(37-154)\end{array}$ & $\begin{array}{l}105 \\
(61.5-157)\end{array}$ & $\begin{array}{l}51 \\
(35-137)\end{array}$ & $0.186^{*}$ \\
\hline GOT (U/l) & $\begin{array}{l}31 \\
(25-48)\end{array}$ & $\begin{array}{l}34.5 \\
(27-55)\end{array}$ & $\begin{array}{l}30 \\
(22-36.5)\end{array}$ & $0.107 *$ \\
\hline GPT (U/l) & $\begin{array}{l}23 \\
(15-33)\end{array}$ & $\begin{array}{l}25.5 \\
(17-35.5)\end{array}$ & $\begin{array}{l}22 \\
(12.5-27)\end{array}$ & $0.134 *$ \\
\hline Creatinin (mg/dl) & $\begin{array}{l}1.13 \\
(0.82-1.59)\end{array}$ & $\begin{array}{l}1.17 \\
(0.83-1.88)\end{array}$ & $\begin{array}{l}1 \\
(0.83-1.13)\end{array}$ & $0.156^{*}$ \\
\hline eGFR (ml/min/BSA) & $\begin{array}{l}49.5 \\
(32-67)\end{array}$ & $\begin{array}{l}46 \\
(27-67)\end{array}$ & $\begin{array}{l}58 \\
(41-66.5)\end{array}$ & $0.213 *$ \\
\hline Blood urea nitrogen (mg/dl) & $\begin{array}{l}46.5 \\
(35-75.5)\end{array}$ & $\begin{array}{l}52 \\
(37.5-97.5)\end{array}$ & $\begin{array}{l}41 \\
(32.5-49.5)\end{array}$ & $0.032 *$ \\
\hline $\mathrm{Na}^{+}(\mathrm{mmol} / \mathrm{l})$ & 139 & 140 & 138 & $0.363^{*}$ \\
\hline
\end{tabular}


Table 2 (continued)

\begin{tabular}{|c|c|c|c|c|}
\hline & Total $(n=50)$ & Symptomatic $(n=31,62 \%)$ & Asymptomatic $(n=19,38 \%)$ & $p$ value \\
\hline & $(136-144)$ & $(136-145)$ & $(136-141)$ & \\
\hline Platelets (G/l) & $\begin{array}{l}187 \\
(150-251)\end{array}$ & $\begin{array}{l}181 \\
(151-238)\end{array}$ & $\begin{array}{l}195 \\
(157-260)\end{array}$ & $0.912 *$ \\
\hline Hemoglobin (g/dl) & $\begin{array}{l}12.2 \\
(11-13.6)\end{array}$ & $\begin{array}{l}12.7 \\
(11.6-13.8)\end{array}$ & $\begin{array}{l}11.6 \\
(10.6-12.9)\end{array}$ & $0.039 *$ \\
\hline WBC (G/l) & $\begin{array}{l}5.54 \\
(4.32-7.88)\end{array}$ & $\begin{array}{l}5.81 \\
(4.12-7.41)\end{array}$ & $\begin{array}{l}5.23 \\
(4.54-8.69)\end{array}$ & $0.639 *$ \\
\hline $\operatorname{ANC}(\mathrm{G} / \mathrm{l})$ & $\begin{array}{l}3.67 \\
(2.81-6.02)\end{array}$ & $\begin{array}{l}3.87 \\
(2.66-5.82)\end{array}$ & $\begin{array}{l}3.55 \\
(3.13-6.97)\end{array}$ & $0.378^{*}$ \\
\hline $\operatorname{ALC}(\mathrm{G} / \mathrm{l})$ & $\begin{array}{l}0.85 \\
(0.62-1.15)\end{array}$ & $\begin{array}{l}0.87 \\
(0.62-1.17)\end{array}$ & $\begin{array}{l}0.79 \\
(0.64-1.04)\end{array}$ & $0.750 *$ \\
\hline
\end{tabular}

*Wilcoxon rank-sum test

$\S$ vitamin $\mathrm{K}$ antagonists, new oral anticoagulants or low-molecular-weight heparin

$A C E$, angiotensin-converting enzyme; $A L C$, absolute lymphocyte count; $A N C$, absolute neutrophil count; $A R B$, angiotensin receptor blocker; $B S A$, body surface area; $C R P, \mathrm{C}$-reactive protein; $e G F R$, estimated glomerular filtration rate; GOT, glutamate-oxaloacetate transaminase; GPT, glutamine phenylpyruvate transaminase; $I L-6$, interleukin $6 ; L D H$, lactate dehydrogenase; NSAID, non-steroidal antiinflammatory drug; $P T T$, partial thromboplastin time; $W B C$, white blood cell count

COVID-19-directed treatment

Tocilizumab was applied in six patients due to COVID19 pneumonia with respiratory deterioration and laboratory signs of hyperinflammation. Dexamethasone was initiated due to COVID-19 pneumonia in one patient. None of the residents received remdesivir, hydroxychloroquine, or convalescent plasma.

Length of hospital stay

The median length of hospital stay was 21 days (IQR: 7-29) in the overall population and 27 days (IQR: $21-$ 34) in patients without in-hospital death. Asymptomatic residents and symptomatic residents at admission could be discharged after a median of 27 days from the COVID-19 unit ( $p=0.66)$.

Discharge probability and 30-day mortality rate

Although the median time to the first negative SARSCoV-2 RT-PCR from nasopharyngeal swabs was 11 days, it took a median of 17 days until documentation of two serial negative nasopharyngeal swabs. In total, two patients were transferred to the intensive care unit (ICU) due to respiratory deterioration. While 33 residents (66\%) could be discharged from the COVID-19 unit to the longterm care facilities or to another non-infectious ward, 17 patients (34\%) succumbed to the COVID-19 infection
(Fig. 1). The 30-day mortality rate from hospitalization was $32 \%$ (Fig. 2). One patient died from COVID-19associated cardiovascular complications on another medical ward after release from quarantine. The cumulative discharge and death probability according to the presence or absence of clinical symptoms at admission are depicted in Fig. 3. Overall survival from admission to the COVID19 unit in symptomatic residents was statistically significantly worse compared to asymptomatic residents including pre-symptomatic residents (median not reached in both groups, HR 6.18 [95\% CI: 1.41-27.07], $p=0.02$ Cox proportional hazard model, Fig. 4). The presence/ absence of COVID-19-associated symptoms at admission as well as the development of symptoms during the hospital stay had a statistically significant impact on survival ( $p=0.016$ log-rank, Fig. 5).

Comparison of baseline characteristics, comorbidities, co-medication, and laboratory values between survivors and non-survivors

The time interval between symptom onset and RT-PCR testing was statistically significantly shorter among survivors compared to non-survivors (median: 0 days versus 1.5 days, $p=0.029$ ). While $94 \%$ of non-survivors developed a new or increased oxygen demand during the course of disease, this was only the case in $48 \%$ of survivors ( $p=0.006)$. Fever ( $69 \%$ versus $38 \%, p=0.044)$, fatigue ( $63 \%$ versus $18 \%, p=0.002)$, and new onset or 
Fig. 1 Cumulative incidence of discharge or death among 50 long-term care facility residents. $y$-axis: probability of discharge or death, $x$-axis: time in days from admission

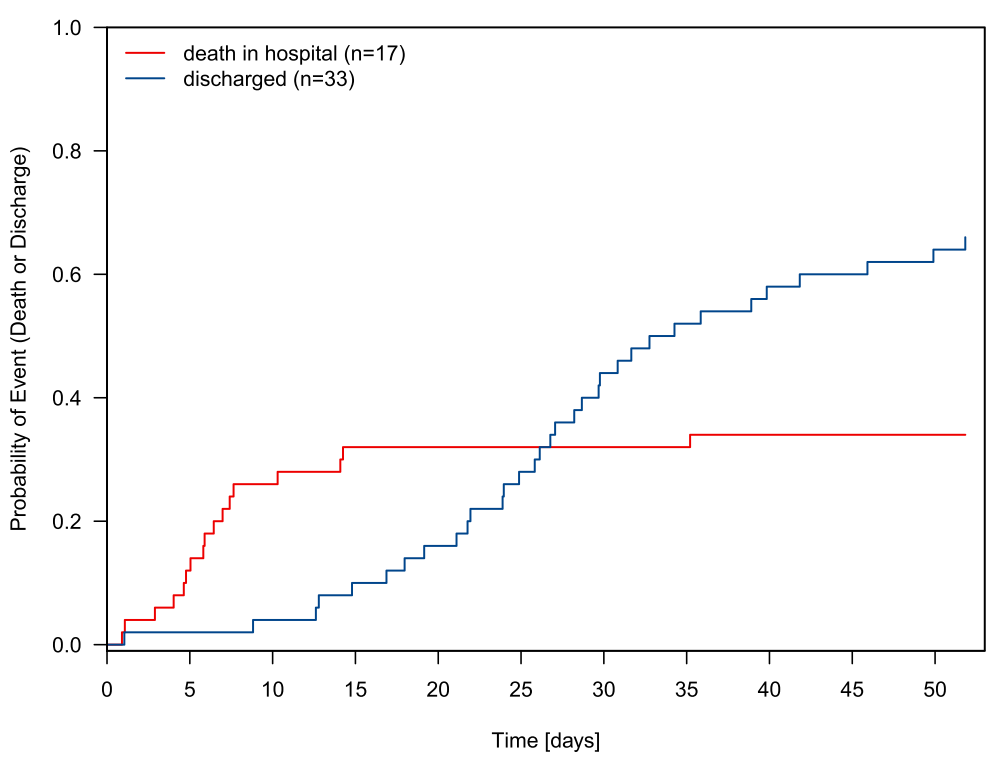

deterioration of confusion ( $37 \%$ versus $12 \%, p=0.034$ ) at admission to the COVID-19 unit were more frequently documented in non-survivors in comparison to survivors. The frequency of cognitive impairment was higher among residents that succumbed to COVID-19 (100\% versus $82 \%, p=0.029)$. Higher baseline levels of ferritin (800.5 versus $337.5 \mathrm{mcg} / \mathrm{l}, p=0.013)$, procalcitonin $(0.2$ versus $0.1, p=0.018)$, D-dimer $(2.8$ versus 0.87 , $p=0.007)$, LDH (303 versus $243 \mathrm{U} / 1, p=0.041)$, GOT (51 versus $30 \mathrm{U} / 1, p=0.003$ ), plasma sodium (142.5 versus $138 \mathrm{mmol} / \mathrm{l}, p=0.014)$, and blood urea nitrogen (76 versus $39.5 \mathrm{mg} / \mathrm{dl}, p<0.001$ ) were measured in nonsurvivors compared to survivors whereas baseline estimated glomerular filtration rate (eGFR) was statistically significantly higher in survivors (55 versus $33 \mathrm{ml} / \mathrm{min} /$ BSA, $p=0.019$ ) (Table 3).
Fig. 2 Overall survival from admission to the COVID-19 unit among 50 long-term care facility residents. $y$-axis: survival probability, $x$-axis: time in days from admission. Tick marks on the curve represent censored patients

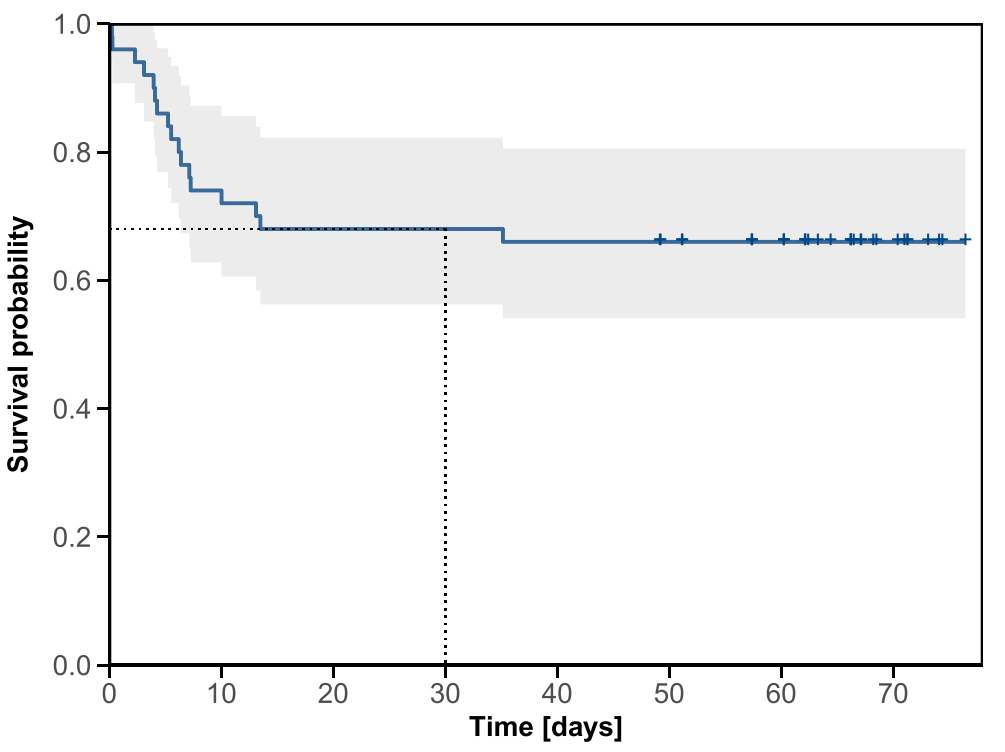

Number at risk

\begin{tabular}{|llllllll|}
\hline 50 & 37 & 34 & 34 & 33 & 31 & 26 & 8 \\
\hline
\end{tabular}


Fig. 3 Cumulative incidence of discharge or death according to COVID-19 symptoms at hospital admission. $y$-axis: cumulative death or discharge probability, $x$ axis: time in days from admission

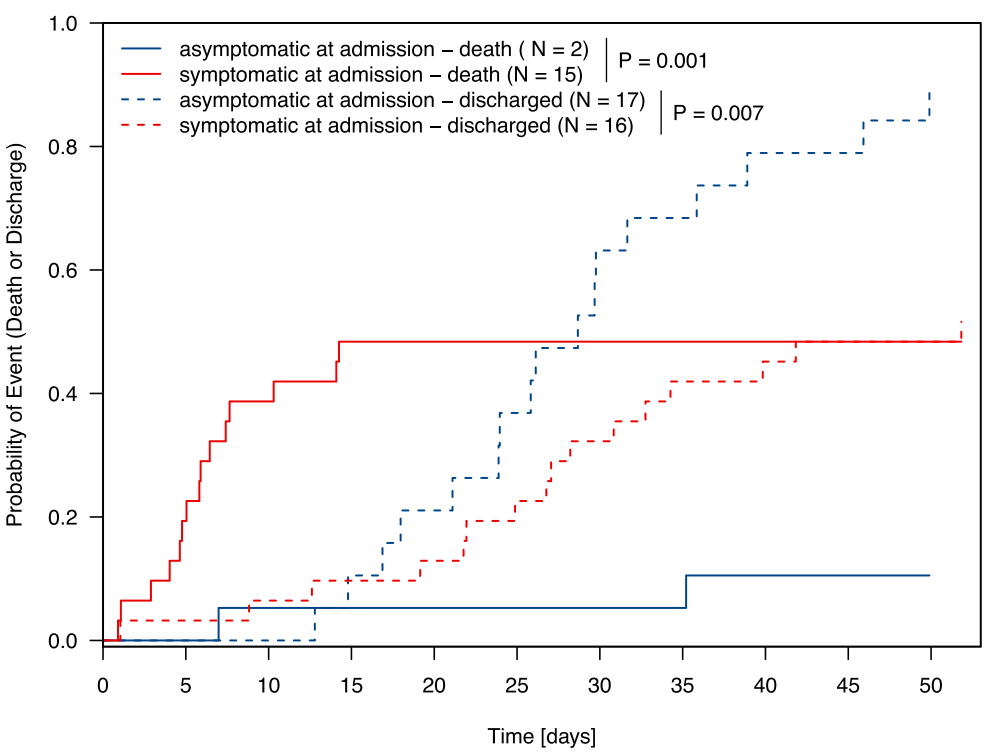

Early Warning Score and association with clinical outcome

The EWS at admission to the COVID-19 unit was available in 49 residents. The baseline EWS turned out to be prognostic for the 30-day mortality rate among COVID-19-positive residents: EWS high risk: 100\%, EWS intermediate risk: $50 \%$ (95\% CI: 0
78\%), and EWS low risk: 21\% (95\% CI: 7-32\%), $p<0.001$ (Fig. 6). Compared to a low-risk EWS (0-4 points), a high-risk EWS ( $\geq 7$ points) was associated with a worse overall survival (HR 17.92 [95\% CI 4.84-66.37], $p<0.001)$. No statistically significant difference was observed between the intermediate (5-6 points) and low-risk group (HR 2.83 [95\% CI 0.7610.53], $p=0.12$ ).
Fig. 4 Overall survival according to COVID-19 symptoms at hospital admission among 50 longterm care facility residents. $y$-axis survival probability, $x$-axis: time in days from admission. Tick marks on the curves represent censored patients; dashed vertical line depicts 30-day cut-off

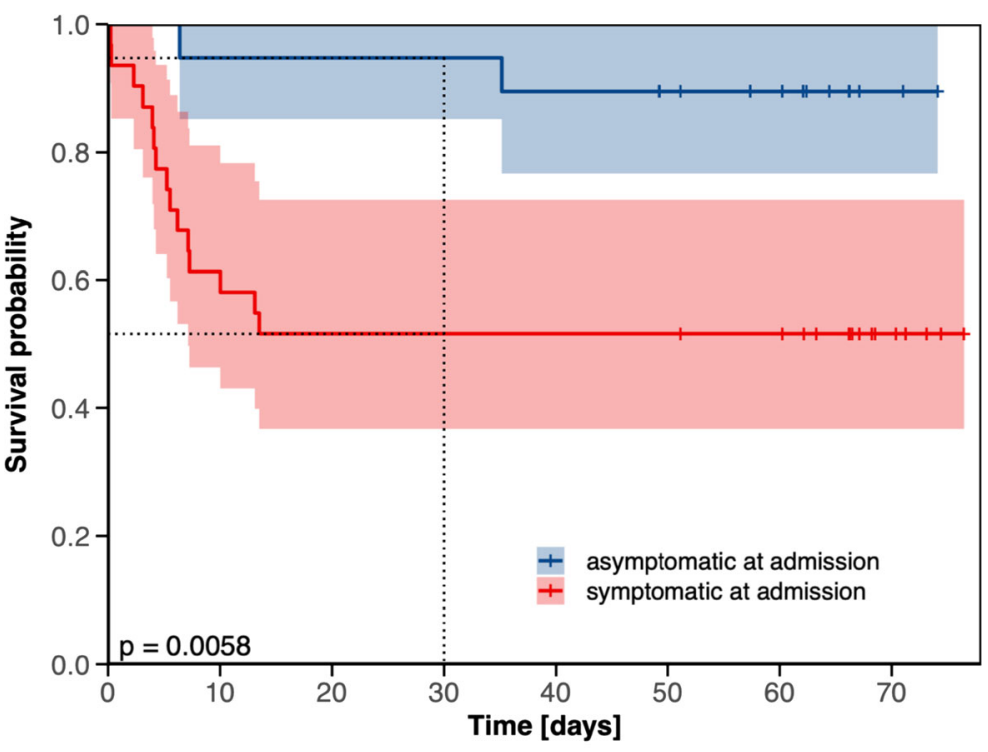

Number at risk

\begin{tabular}{|llllllll|}
\hline 19 & 18 & 18 & 18 & 17 & 15 & 11 & 2 \\
31 & 19 & 16 & 16 & 16 & 16 & 15 & 6 \\
\hline
\end{tabular}


Fig. 5 Overall survival according to COVID-19 symptoms during the course of disease among 50 long-term care facility residents. $y$-axis: survival probability, $x$-axis: time in days from admission. Tick marks on the curves represent censored patients; dashed vertical line depicts 30-day cutoff

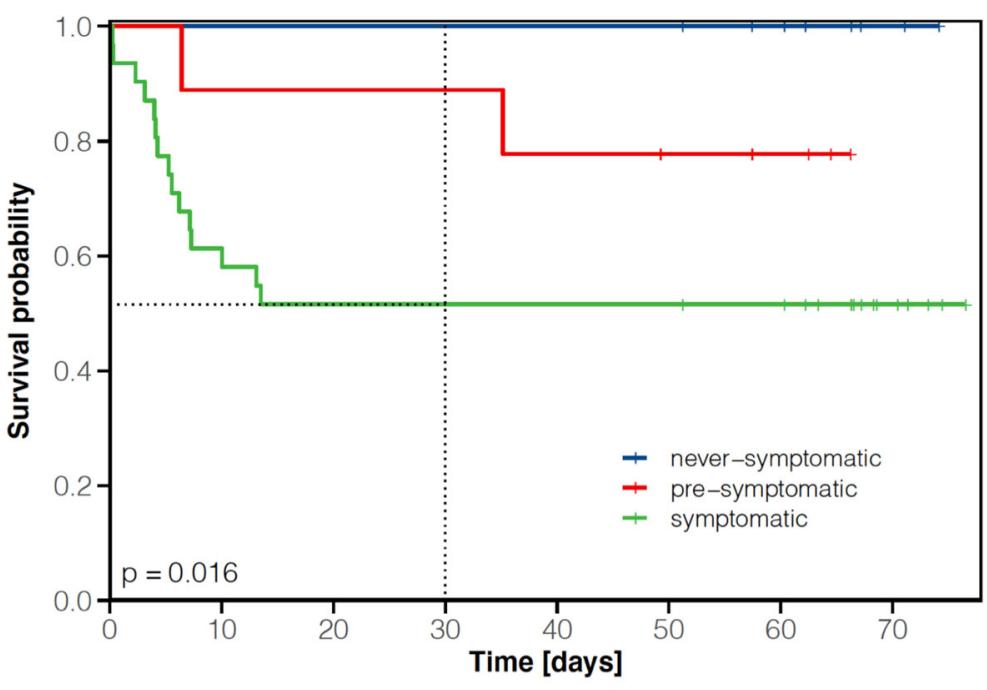

Number at risk

$-$\begin{tabular}{cccccccc|}
\hline 10 & 10 & 10 & 10 & 10 & 10 & 8 & 2 \\
9 & 8 & 8 & 8 & 7 & 5 & 3 & 0 \\
31 & 19 & 16 & 16 & 16 & 16 & 15 & 6 \\
\hline
\end{tabular}

\section{Discussion}

People of advanced age and particular residents of longterm care facilities face a high death toll and excess mortality from COVID-19 in most countries in the world [17]. Several strategies have been proposed to selectively protect this extremely vulnerable population from infection, severe morbidity, and death. Unfortunately, however, such approaches were either not implemented or not successful during the first wave and apparently not even during the second wave of the pandemic 8 to 9 months later, despite much better availability of PPE and testing capacity, some effective medication, and even better medical experience with the disease. The approval status of COVID-19 vaccines for elderly people as well as the progress of COVID-19 vaccination programs for high-risk groups such as long-term care facility residents is highly variable between various countries and parts of the world. These issues raise the question how to better deal with these vulnerable cohorts.

To the best of our knowledge, this is the first investigation of a hospitalization policy of COVID-19positive long-term care facility residents irrespective of symptoms. The approach to hospitalize symptomatic and asymptomatic COVID-19-positive residents in the Province of Salzburg enabled us to closely monitor the course of disease in this geriatric and comorbid cohort in a well-equipped setting. In our cohort, the median length of hospital stay was 21 days (IQR: 7-29) in the overall population and 27 days (IQR: $21-34$ ) in patients without in-hospital death. One out of three hospitalized residents succumbed to the COVID-19 infection, corroborating the high mortality rate in this vulnerable population [3-6]. Notably, the majority of deaths were derived from symptomatic residents at admission (Figs. 3, 4, and 5). In our cohort, roughly every other asymptomatic resident at admission developed COVID-19-associated symptoms during the course of the hospital stay. We thus confirm that asymptomatic SARS-CoV-2 infection is seen in a relevant percentage even in elderly and comorbid residents of long-term care facilities [18]. However, due to diagnoses often made during screening efforts tracking local outbreaks, we observed a significant number of pre-symptomatic patients, being diagnosed very early in their course of disease and with a relatively low likelihood of a strong selection bias.

Although this has not been tested in a controlled, prospective manner, we observed a comparably encouraging clinical outcome in pre-symptomatic and asymptomatic residents by applying the following measures during the hospital stay.

Medical rounds were scheduled on a daily regular basis with the possibility of repeated visits according to the patients' disease severity and demands. Due to the frequently observed at least temporary immobility and 
Table 3 Baseline characteristics according to 30-day mortality of 50 long-term care facility residents admitted to the COVID-19 unit

\begin{tabular}{|c|c|c|c|c|}
\hline & Total $(n=50)$ & Dead $(n=16,32 \%)$ & Alive $(n=34,68 \%)$ & $p$ value \\
\hline Age (median, IQR) & $\begin{array}{l}84.5 \\
(79-88)\end{array}$ & $\begin{array}{l}85.5 \\
(77-87)\end{array}$ & $\begin{array}{l}83.5 \\
(79-89)\end{array}$ & $0.819^{*}$ \\
\hline Sex & & & & 0.567 \\
\hline Female & $34(68)$ & $10(63)$ & $24(71)$ & \\
\hline Male & $16(32)$ & $6(37)$ & $10(29)$ & \\
\hline EWS at admission (median, IQR) & $\begin{array}{l}3 \\
(1-4)\end{array}$ & $\begin{array}{l}4 \\
(3-6)\end{array}$ & $\begin{array}{l}2 \\
(0-3)\end{array}$ & $<0.001 *$ \\
\hline New or increased oxygen demand at admission & & & & 0.108 \\
\hline No & $30(60)$ & $7(44)$ & $23(68)$ & \\
\hline Yes & $20(40)$ & $9(56)$ & $11(32)$ & \\
\hline New or increased oxygen demand at COVID-19 unit & & & & 0.006 \\
\hline No & $18(37)$ & $1(6)$ & $17(52)$ & \\
\hline Yes & $31(63)$ & $15(94)$ & $16(48)$ & \\
\hline Unknown & 1 & 0 & 1 & \\
\hline Time from symptom onset to SARS-CoV-2 test (days) & $\begin{array}{l}0 \\
(-1-4)\end{array}$ & $\begin{array}{l}1.5 \\
(0-4)\end{array}$ & $\begin{array}{l}0 \\
(-3-2)\end{array}$ & $0.029 *$ \\
\hline ICU transfer & & & & 0.578 \\
\hline No & $48(96)$ & $15(94)$ & $33(97 \%)$ & \\
\hline Yes & $2(4)$ & $1(6)$ & $1(3)$ & \\
\hline \multicolumn{5}{|l|}{ Clinical symptoms at admission } \\
\hline Fever $\left(>37.5^{\circ} \mathrm{C}\right)$ & & & & 0.044 \\
\hline No & $26(52)$ & $5(31)$ & $21(62)$ & \\
\hline Yes & $24(48)$ & $11(69)$ & $13(38)$ & \\
\hline Dyspnea & & & & 0.827 \\
\hline No & $27(54)$ & $9(56)$ & $18(53)$ & \\
\hline Yes & $23(46)$ & $7(44)$ & $16(47)$ & \\
\hline Cough & & & & 0.960 \\
\hline No & $31(62)$ & $10(63)$ & $21(62)$ & \\
\hline Yes & $19(38)$ & $6(37)$ & $13(38)$ & \\
\hline Headache & & & & NA \\
\hline No & $50(100)$ & $16(100)$ & $34(100)$ & \\
\hline Yes & $0(0)$ & $0(0)$ & $0(0)$ & \\
\hline Chills & & & & 0.141 \\
\hline No & $49(98)$ & $15(94)$ & $34(100)$ & \\
\hline Yes & $1(2)$ & $1(6)$ & $0(0)$ & \\
\hline Sore throat & & & & NA \\
\hline No & 49 (100) & $15(100)$ & $34(100)$ & \\
\hline Yes & $0(0)$ & $0(0)$ & $0(0)$ & \\
\hline Unknown & 1 & 1 & 0 & \\
\hline Rhinorrhea & & & & NA \\
\hline No & $50(100)$ & $16(100)$ & $34(100)$ & \\
\hline Yes & $0(0)$ & $0(0)$ & $0(0)$ & \\
\hline Diarrhea & & & & 0.959 \\
\hline No & $47(94)$ & $15(94)$ & $32(94)$ & \\
\hline Yes & $3(6)$ & $1(6)$ & $2(6)$ & \\
\hline
\end{tabular}


Table 3 (continued)

\begin{tabular}{|c|c|c|c|c|}
\hline & Total $(n=50)$ & Dead $(n=16,32 \%)$ & Alive $(n=34,68 \%)$ & $p$ value \\
\hline Fatigue & & & & 0.002 \\
\hline No & $40(80)$ & $6(37)$ & $28(82)$ & \\
\hline Yes & $10(20)$ & $10(63)$ & $6(18)$ & \\
\hline Myalgia/painful joints & & & & 0.141 \\
\hline No & $49(98)$ & $15(94)$ & $34(100)$ & \\
\hline Yes & $1(2)$ & $1(6)$ & $0(0)$ & \\
\hline Deteriorated confusion & & & & 0.034 \\
\hline No & $40(80)$ & $10(63)$ & $30(88)$ & \\
\hline Yes & $10(20)$ & $6(37)$ & $4(12)$ & \\
\hline \multicolumn{5}{|l|}{ Comorbidities } \\
\hline Number of comorbidities (median, IQR) & $\begin{array}{l}6 \\
(4-7)\end{array}$ & $\begin{array}{l}5 \\
(4-6)\end{array}$ & $\begin{array}{l}6 \\
(4-7)\end{array}$ & 0.462 \\
\hline Chronic lung disease & & & & 0.391 \\
\hline No & $44(88)$ & $15(94)$ & $29(85)$ & \\
\hline Yes & $6(12)$ & $1(6)$ & $5(15)$ & \\
\hline Cardiac disease ${ }^{\#}$ & & & & 0.981 \\
\hline No & $22(44)$ & $7(44)$ & $15(44)$ & \\
\hline Yes & $28(56)$ & $9(56)$ & $19(56)$ & \\
\hline Hypertension & & & & 0.834 \\
\hline No & $7(14)$ & $2(12)$ & $5(15)$ & \\
\hline Yes & $43(86)$ & $14(88)$ & $29(85)$ & \\
\hline Diabetes mellitus type 2 & & & & 0.467 \\
\hline No & $34(68)$ & $12(75)$ & $22(65)$ & \\
\hline Yes & $16(32)$ & $4(25)$ & $12(35)$ & \\
\hline Cerebrovascular disease & & & & 0.726 \\
\hline No & $36(72)$ & $11(69)$ & $25(74)$ & \\
\hline Yes & $14(28)$ & $5(31)$ & $9(26)$ & \\
\hline Vascular disease & & & & 0.106 \\
\hline No & $45(90)$ & $16(100)$ & $29(85)$ & \\
\hline Yes & $5(10)$ & $0(0)$ & $5(15)$ & \\
\hline Chronic kidney disease & & & & 0.680 \\
\hline No & $26(52)$ & $9(56)$ & $17(50)$ & \\
\hline Yes & $24(48)$ & $7(44)$ & $17(50)$ & \\
\hline Neurodegenerative disease & & & & 0.716 \\
\hline No & $38(78)$ & $13(81)$ & $25(76)$ & \\
\hline Yes & $11(22)$ & $3(19)$ & $8(24)$ & \\
\hline Unknown & 1 & 0 & 1 & \\
\hline Cognitive impairment & & & & 0.029 \\
\hline No & $6(12)$ & $0(0)$ & $6(18)$ & \\
\hline Yes & $42(88)$ & $14(100)$ & $28(82)$ & \\
\hline Unknown & 2 & 2 & 0 & \\
\hline Active hematologic disease & & & & 0.141 \\
\hline No & $49(98)$ & $15(94)$ & $34(100)$ & \\
\hline Yes & $1(2)$ & $1(6)$ & $0(0)$ & \\
\hline
\end{tabular}


Table 3 (continued)

\begin{tabular}{|c|c|c|c|c|}
\hline & Total $(n=50)$ & Dead $(n=16,32 \%)$ & Alive $(n=34,68 \%)$ & $p$ value \\
\hline Active oncologic disease & & & & 0.421 \\
\hline No & $46(92)$ & $14(88)$ & $32(94)$ & \\
\hline Yes & $4(8)$ & $2(12)$ & $2(6)$ & \\
\hline Thyroid disorder & & & & 0.912 \\
\hline No & $37(74)$ & $12(75)$ & $25(74)$ & \\
\hline Yes & $13(26)$ & $4(25)$ & $9(26)$ & \\
\hline History of thromboembolic events & & & & 0.925 \\
\hline No & $41(82)$ & $13(81)$ & $28(82)$ & \\
\hline Yes & $9(18)$ & $3(19)$ & $6(18)$ & \\
\hline Autoimmune disease & & & & NA \\
\hline No & $50(100)$ & $16(100)$ & $34(100)$ & \\
\hline Yes & $0(0)$ & $0(0)$ & $0(0)$ & \\
\hline \multicolumn{5}{|l|}{ Co-medication at admission } \\
\hline Number of medication classes & 5 & 4 & 5 & $0.291 *$ \\
\hline (median, IQR) & $(3-6)$ & $(3-5)$ & $(4-6)$ & \\
\hline ACE inhibitor & & & & 0.597 \\
\hline No & $35(70)$ & $12(75)$ & $23(68)$ & \\
\hline Yes & $15(30)$ & $4(25)$ & $11(32)$ & \\
\hline ARBs & & & & 0.544 \\
\hline No & $40(80)$ & $12(75)$ & $28(82)$ & \\
\hline Yes & $10(20)$ & $4(25)$ & $6(18)$ & \\
\hline Other antihypertensive therapy & & & & 0.720 \\
\hline No & $17(34)$ & $6(37)$ & $11(32)$ & \\
\hline Yes & $33(66)$ & $10(63)$ & $23(68)$ & \\
\hline Antibiotics & & & & 0.314 \\
\hline No & $44(88)$ & $13(81)$ & $31(91)$ & \\
\hline Yes & $6(12)$ & $3(19)$ & $3(9)$ & \\
\hline Proton pump inhibitors & & & & 0.846 \\
\hline No & $24(48)$ & $8(50)$ & $16(47)$ & \\
\hline Yes & $26(52)$ & $8(50)$ & $18(53)$ & \\
\hline Statins & & & & 0.910 \\
\hline No & $38(76)$ & $12(75)$ & $26(77)$ & \\
\hline Yes & $12(24)$ & $4(25)$ & $8(23)$ & \\
\hline NSAIDs & & & & 0.391 \\
\hline No & $44(88)$ & $15(94)$ & $29(85)$ & \\
\hline Yes & $6(12)$ & $1(6)$ & $5(15)$ & \\
\hline Opiates & & & & 0.168 \\
\hline No & $34(68)$ & $13(81)$ & $21(62)$ & \\
\hline Yes & $16(32)$ & $3(19)$ & $13(38)$ & \\
\hline Long-term systemic steroid therapy ( $\geq 14$ days) & & & & 0.488 \\
\hline No & $49(98)$ & $16(100)$ & $33(97)$ & \\
\hline Yes & $1(2)$ & $0(0)$ & $1(3)$ & \\
\hline Short-term systemic steroid therapy ( $<14$ days) & & & & 0.488 \\
\hline No & $49(98)$ & $16(100)$ & $33(97)$ & \\
\hline Yes & $1(2)$ & $0(0)$ & $1(3)$ & \\
\hline
\end{tabular}


Table 3 (continued)

\begin{tabular}{|c|c|c|c|c|}
\hline & Total $(n=50)$ & Dead $(n=16,32 \%)$ & Alive $(n=34,68 \%)$ & $p$ value \\
\hline Inhaled steroid therapy & & & & 0.220 \\
\hline No & 47 (94) & $16(100)$ & $31(91)$ & \\
\hline Yes & $3(6)$ & $0(0)$ & $3(9)$ & \\
\hline Antidiabetic therapy (excluding insulin) & & & & 0.507 \\
\hline No & $43(86)$ & $13(81)$ & $30(88)$ & \\
\hline Yes & $7(14)$ & $3(19)$ & $4(12)$ & \\
\hline Insulin therapy & & & & 0.391 \\
\hline No & $44(88)$ & $15(94)$ & $29(85)$ & \\
\hline Yes & $6(12)$ & $1(6)$ & $5(15)$ & \\
\hline Psychopharmacologic therapy & & & & 0.567 \\
\hline No & $16(32)$ & $6(37)$ & $10(29)$ & \\
\hline Yes & $34(68)$ & $10(63)$ & $24(71)$ & \\
\hline Anticoagulation therapy (therapeutic dose) $)^{\S}$ & & & & 0.357 \\
\hline No & $33(66)$ & $12(75)$ & $21(62)$ & \\
\hline Yes & $17(34)$ & $4(25)$ & $13(38)$ & \\
\hline Antiplatelet therapy & & & & 0.912 \\
\hline No & $37(74)$ & $12(75)$ & $25(74)$ & \\
\hline Yes & $13(26)$ & $4(25)$ & $9(26)$ & \\
\hline \multicolumn{5}{|l|}{ Laboratory values (IQR) } \\
\hline $\mathrm{CRP}(\mathrm{mg} / \mathrm{dl})$ & $\begin{array}{l}4.8 \\
(1.5-12)\end{array}$ & $\begin{array}{l}7.4 \\
(3.6-13.2)\end{array}$ & $\begin{array}{l}4.6 \\
(1.4-10.9)\end{array}$ & $0.253 *$ \\
\hline Peak CRP (mg/dl) & $\begin{array}{l}10.1 \\
(4.4-16.3)\end{array}$ & $\begin{array}{l}11.6 \\
(5.4-16.9)\end{array}$ & $\begin{array}{l}9 \\
(4.3-16)\end{array}$ & $0.355^{*}$ \\
\hline IL-6 (pg/ml) & $\begin{array}{l}36.9 \\
(20.8-102)\end{array}$ & $\begin{array}{l}63.3 \\
(23.4-137.5)\end{array}$ & $\begin{array}{l}30.4 \\
(14.3-80.8)\end{array}$ & $0.067 *$ \\
\hline Peak IL-6 (pg/ml) & $\begin{array}{l}72.9 \\
(33.1-231)\end{array}$ & $\begin{array}{l}145 \\
(59.1-279)\end{array}$ & $\begin{array}{l}61.4 \\
(29.2-182)\end{array}$ & $0.159 *$ \\
\hline Ferritin $(\mathrm{mcg} / \mathrm{l})$ & $\begin{array}{l}426.5 \\
(196-910)\end{array}$ & $\begin{array}{l}800.5 \\
(436.5-1211.5)\end{array}$ & $\begin{array}{l}337.5 \\
(156-550)\end{array}$ & $0.013 *$ \\
\hline Peak ferritin (mcg/l) & $\begin{array}{l}540.5 \\
(300.5-1323)\end{array}$ & $\begin{array}{l}1255 \\
(514.5-2079)\end{array}$ & $\begin{array}{l}445.5 \\
(274-852.5)\end{array}$ & $0.006^{*}$ \\
\hline Procalcitonin (mcg/l) & $\begin{array}{l}0.1 \\
(0.1-0.2)\end{array}$ & $\begin{array}{l}0.2 \\
(0.1-0.6)\end{array}$ & $\begin{array}{l}0.1 \\
(0.1-0.1)\end{array}$ & $0.018 *$ \\
\hline Peak procalcitonin $(\mathrm{mcg} / \mathrm{l})$ & $\begin{array}{l}0.2 \\
(0.1-0.5)\end{array}$ & $\begin{array}{l}0.4 \\
(0.2-0.9)\end{array}$ & $\begin{array}{l}0.1 \\
(0.1-0.4)\end{array}$ & $0.025 *$ \\
\hline ATIII $(\%)$ & $\begin{array}{l}87 \\
(77-99.5)\end{array}$ & $\begin{array}{l}82 \\
(76-98)\end{array}$ & $\begin{array}{l}88 \\
(79-103)\end{array}$ & $0.548 *$ \\
\hline D-dimer (mg/l) & $\begin{array}{l}1.02 \\
(0.65-2.80)\end{array}$ & $\begin{array}{l}2.8 \\
(1.26-5.95)\end{array}$ & $\begin{array}{l}0.87 \\
(0.59-1.68)\end{array}$ & $0.007 *$ \\
\hline Fibrinogen (mg/dl) & $\begin{array}{l}443 \\
(346-483)\end{array}$ & $\begin{array}{l}449.5 \\
(420.5-487)\end{array}$ & $\begin{array}{l}409 \\
(338-469)\end{array}$ & $0.364 *$ \\
\hline PTZ (\%) & $\begin{array}{l}75 \\
(68-88)\end{array}$ & $\begin{array}{l}72.5 \\
(63-84)\end{array}$ & $\begin{array}{l}79 \\
(69-88)\end{array}$ & $0.557^{*}$ \\
\hline PTT (s) & $\begin{array}{l}35 \\
(31-38)\end{array}$ & $\begin{array}{l}36.5 \\
(32-41)\end{array}$ & $\begin{array}{l}34 \\
(31-36)\end{array}$ & $0.325^{*}$ \\
\hline LDH (U/l) & $\begin{array}{l}279 \\
(209.5-312)\end{array}$ & $\begin{array}{l}303 \\
(281-372)\end{array}$ & $\begin{array}{l}243 \\
(191.5-309)\end{array}$ & $0.041 *$ \\
\hline Hs troponin T (ng/l) & $\begin{array}{l}36 \\
(24-49)\end{array}$ & $\begin{array}{l}46 \\
(34.5-66.5)\end{array}$ & $\begin{array}{l}36 \\
(23-48)\end{array}$ & $0.187 *$ \\
\hline Creatine kinase (U/l) & $\begin{array}{l}70 \\
(37-154)\end{array}$ & $\begin{array}{l}98 \\
(81.5-359.5)\end{array}$ & $\begin{array}{l}61.5 \\
(37-141.5)\end{array}$ & $0.088 *$ \\
\hline
\end{tabular}


Table 3 (continued)

\begin{tabular}{|c|c|c|c|c|}
\hline & Total $(n=50)$ & Dead $(n=16,32 \%)$ & Alive $(n=34,68 \%)$ & $p$ value \\
\hline GOT (U/l) & $\begin{array}{l}31 \\
(25-48)\end{array}$ & $\begin{array}{l}51 \\
(32-69)\end{array}$ & $\begin{array}{l}30 \\
(22-37)\end{array}$ & $0.003 *$ \\
\hline GPT (U/l) & $\begin{array}{l}23 \\
(15-33)\end{array}$ & $\begin{array}{l}29 \\
(16-36)\end{array}$ & $\begin{array}{l}22 \\
(14-32)\end{array}$ & $0.182 *$ \\
\hline Creatinin (mg/dl) & $\begin{array}{l}1.13 \\
(0.82-1.59)\end{array}$ & $\begin{array}{l}1.55 \\
(0.98-3.30)\end{array}$ & $\begin{array}{l}1.03 \\
(0.82-1.22)\end{array}$ & $0.052 *$ \\
\hline eGFR (ml/min/BSA) & $\begin{array}{l}49.5 \\
(32-67)\end{array}$ & $\begin{array}{l}33 \\
(15.5-54.5)\end{array}$ & $\begin{array}{l}55 \\
(41-68)\end{array}$ & $0.019 *$ \\
\hline Blood urea nitrogen (mg/dl) & $\begin{array}{l}46.5 \\
(35-75.5)\end{array}$ & $\begin{array}{l}76 \\
(51-116)\end{array}$ & $\begin{array}{l}39.5 \\
(29.5-51.5)\end{array}$ & $<0.001 *$ \\
\hline $\mathrm{Na}^{+}(\mathrm{mmol} / \mathrm{l})$ & $\begin{array}{l}139 \\
(136-144)\end{array}$ & $\begin{array}{l}142.5 \\
(139-150)\end{array}$ & $\begin{array}{l}138 \\
(135-142)\end{array}$ & $0.014 *$ \\
\hline Platelets (G/l) & $\begin{array}{l}187 \\
(150-251)\end{array}$ & $\begin{array}{l}150 \\
(142-216)\end{array}$ & $\begin{array}{l}196 \\
(170-270)\end{array}$ & $0.060 *$ \\
\hline Hemoglobin (mg/dl) & $\begin{array}{l}12.2 \\
(11-13.4)\end{array}$ & $\begin{array}{l}12.6 \\
(11.1-13.6)\end{array}$ & $\begin{array}{l}12.2 \\
(11-13.4)\end{array}$ & $0.662 *$ \\
\hline WBC (G/l) & $\begin{array}{l}5.54 \\
(4.32-7.88)\end{array}$ & $\begin{array}{l}6.73 \\
(4.68-8.21)\end{array}$ & $\begin{array}{l}5.15 \\
(4.16-7.76)\end{array}$ & $0.303 *$ \\
\hline $\mathrm{ANC}(\mathrm{G} / \mathrm{l})$ & $\begin{array}{l}3.67 \\
(2.81-6.02)\end{array}$ & $\begin{array}{l}4.99 \\
(3.40-6.59)\end{array}$ & $\begin{array}{l}3.38 \\
(2.74-5.59)\end{array}$ & $0.168 *$ \\
\hline $\operatorname{ALC}(\mathrm{G} / \mathrm{l})$ & $\begin{array}{l}0.85 \\
(0.62-1.15)\end{array}$ & $\begin{array}{l}0.8 \\
(0.58-1.14)\end{array}$ & $\begin{array}{l}0.87 \\
(0.65-1.14)\end{array}$ & $0.441 *$ \\
\hline
\end{tabular}

*Wilcoxon rank-sum test

${ }^{\#}$ Coronary heart disease, chronic heart failure, arrhythmia, and/or heart valve disease

$\S$ Vitamin $\mathrm{K}$ antagonists, new oral anticoagulants, or low-molecular-weight heparin

$A C E$, angiotensin-converting enzyme; $A L C$, absolute lymphocyte count; $A N C$, absolute neutrophil count; $A R B$, angiotensin receptor blocker; $B S A$, body surface area; $C R P$, C-reactive protein; $e G F R$, estimated glomerular filtration rate; GOT, glutamate-oxaloacetate transaminase; $G P T$, glutamine phenylpyruvate transaminase; $I L-6$, interleukin $6 ; L D H$, lactate dehydrogenase; NSAID, non-steroidal antiinflammatory drug; $P T T$, partial thromboplastin time; $W B C$, white blood cell count

Fig. 6 Overall survival according to baseline EWS among 49 longterm care facility residents with available EWS. $y$-axis: survival probability, $x$-axis: time in days from admission. Tick marks on the curves represent censored patients; dashed vertical line depicts 30-day cut-off

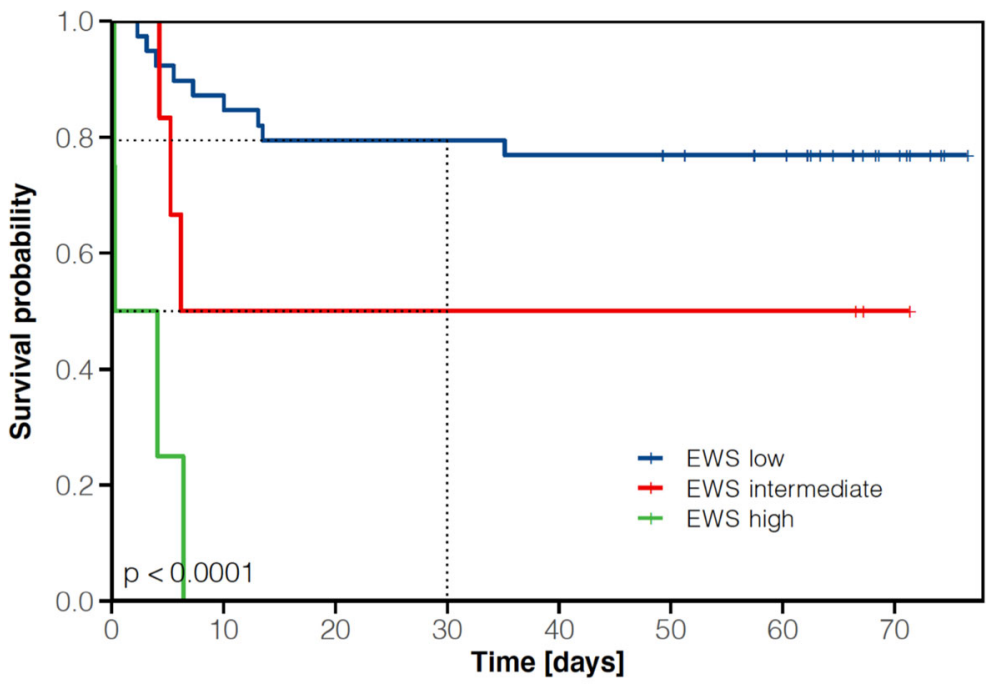

Number at risk

$-$\begin{tabular}{cccccccc|}
39 & 34 & 31 & 31 & 30 & 28 & 23 & 7 \\
6 & 3 & 3 & 3 & 3 & 3 & 3 & 1 \\
4 & 0 & 0 & 0 & 0 & 0 & 0 & 0 \\
\hline
\end{tabular}


the procoagulant state associated with a COVID-19 infection $[19,20]$, all hospitalized residents received anticoagulation therapy at least in a prophylactic dose. Hyposmia or anosmia [21] as well as delirium [22] has been regularly reported among SARS-CoV-2-infected people and in turn may result in inadequate nutrient and fluid intake especially among elderly people. Metabolomics analyses demonstrated an altered amino acid and fatty acid metabolism in patients suffering from COVID19 when compared to COVID-19-negative controls [23]. In this regard, the fluid balance was assessed on an individual basis and residents were provided with enteral and/or temporary parenteral nutrition support in case of reduced fluid or nutrient intake. Repeated laboratory testing, blood gas analyses, and imaging studies enabled us to rapidly detect imminent, potentially life-threatening complications such as kidney or respiratory failure and in turn to prompt timely counteractions such as e.g. intravenous fluid support, antibiotic therapy, or transfer to the ICU without delay. Physical therapy was offered to all residents; residents with pulmonary involvement were additionally supported by respiratory therapy. However, due to the limited number of pre-symptomatic residents $(n=9)$, we cannot fully exclude a more indolent course of COVID-19 disease in the pre-symptomatic cohort when compared to symptomatic residents, irrespective of the abovementioned measures.

While $40 \%$ of residents presented with a new or increased oxygen demand at admission to the COVID19 unit, the percentage rose to $60 \%$ during the hospital stay. However, owed to patients' will, advance directives, and comorbidities, only two out of 50 residents were transferred to the ICU. In the meanwhile, study results of several COVID-19 directed therapies have been published. Remdesivir received approval by the Food and Drug Administration for COVID-19-positive hospitalized patients irrespective of disease severity [24, 25], but the large WHO Solidarity Trial could not prove an OS or disease-modifying effect [26]. In contrast, dexamethasone (in case of reduced oxygen saturation or demand for oxygen therapy) provided evidence for a substantial OS benefit in patients hospitalized for COVID-19 [27]. We emphasize that dexamethasone and remdesivir, for which clinical phase III trials have demonstrated an improved clinical outcome in the meanwhile, were not routinely or not applied at all in this cohort, respectively. Based on preliminary released efficacy data [28], tocilizumab was applied in six patients with evidence of respiratory failure and laboratory signs of hyperinflammation of which three residents succumbed to their COVID-19 pneumonia. Although the EMPACTA trial met its primary endpoint, demonstrating a reduced likelihood of needing mechanical ventilation in hospitalized patients with COVID-19 pneumonia [29], a plethora of clinical phase III trials did not show a survival benefit or other clear clinical benefits [30-32] of tocilizumab in COVID-19 disease. These findings together with Roche's recent announcement of negative results from the phase III COVACTA trial [33] and a press release with positive results from the RECOVERY trial [34] shows that the question about the role of IL- 6 receptor blockade in severe COVID-19-associated pneumonia is not yet resolved.

While previous reports described an association between pre-existing coronary artery disease [35, 36], congestive heart failure[35], arrhythmia [35], diabetes [36], and chronic obstructive lung disease [35, 36], respectively, with in-hospital death in hospitalized COVID-19positive patients, COVID-19 associated mortality was not impacted by cardiovascular disease, diabetes mellitus, or chronic obstructive lung disease in our analysis. However, fatigue, pre-existing cognitive impairment, and deterioration or new onset of confusion were associated with an increased likelihood of in-hospital death in this cohort (Table 3), suggesting that the latter symptoms might represent clinically meaningful warning signs in elderly COVID-19-positive people. In this regard, it is interesting to note that infection with SARSCoV-2 has recently been associated with onset of delirium even in afebrile patients and SARS-CoV-2associated delirium turned out to be statistically significantly associated with the likelihood of admission to the ICU as well as with death [22]. Similar observations have been made among hospitalized influenza patients in whom dementia was an independent risk factor for mortality [37]. Early published retrospective data from China did not show an association between the presence of fatigue and mortality among COVID-19-positive patients [36]. However, a considerable difference in median age exists between the latter cohort (56 years) and our geriatric cohort ( 84.5 years) and fatigue has been shown to significantly impact mortality in older adults [38].

Within this geriatric population, $82 \%$ of residents presented with pre-existing hypertension treated with ACE inhibitors or ARBs in $30 \%$ and $20 \%$, respectively (Table 2). SARS-CoV-2 uses the SARS-CoV-2 receptor ACE2 for entry into humans cells [39], and the expression of ACE2 might be increased by ACE inhibitors and 
ARBs according to animal studies [40]. ACE inhibitor and ARB use were not associated with worse survival in our cohort (Table 3), which is in line with retrospective analyses [41] as well as with the results from the randomized, controlled BRACE-CORONA trial [42]. In contrast to previous reports [43], proton pump inhibitor intake did not impact survival among the long-term care facility residents included in our analysis, although proton pump inhibitors were prescribed in more than half of all residents (Table 3). In line with the literature [44], pre-established therapeutic anticoagulation therapy (with either vitamin $\mathrm{K}$ antagonists, new oral anticoagulants, or low-molecular-weight heparin) was equally distributed between survivors and non-survivors (Table 3). In our cohort, each resident received at least anticoagulation therapy in a prophylactic dose; however, whether the latter measure had a beneficial impact on clinical outcome cannot be answered from our data. Preestablished opiate therapy was associated with a lower probability of COVID-19-associated symptoms at admission (Table 2); however, this did not translate into superior OS (Table 3). Literature covering the impact of opiates on symptoms and clinical outcome in COVID19 disease is lacking. The majority of residents (68\%) received psychopharmacologic medication, including antidepressants. In this regard, it is interesting that the selective serotonin reuptake inhibitor fluoxetine has been shown to inhibit SARS-CoV-2 cell entry in the cell culture model [45]. However, the application of psychopharmacologic drugs did not impact clinical symptoms or clinical outcomes in our cohort.

Non-survivors showed statistically significantly higher baseline levels of acute-phase reactants (ferritin, D-dimer) and elevated levels of procalcitonin, suggestive of bacterial superinfection (Table 3). The latter findings in our geriatric cohort are in line with reports from COVID-19-positive hospitalized patients or outpatients in China [2]. Furthermore, higher levels of sodium, blood urea nitrogen, and a worse eGFR, suggestive of reduced fluid intake and dehydration, were observed in non-survivors at baseline (Table 3), arguing for the individual establishment of our recommended measures (fluid balance charts, i.v. hydration, enteral and/or parenteral nutrition support) in asymptomatic as well as pre-symptomatic COVID-19-positive long-term care facility residents in-house.

A statistically significantly longer time interval between symptom onset and RT-PCR testing was found among residents succumbing to COVID-19 disease when compared to survivors (median: 1.5 days versus 0 days, $p=0.029$ ), suggesting rapid RT-PCR testing in case of a clinically suspected COVID-19 infection and subsequent immediate hospitalization in case of test positivity in symptomatic residents.

In clinical practice, it is of utmost importance to rapidly and repeatedly assess the clinical condition in hospitalized COVID-19 patients, in particular, in case of high bed occupancy rates and limited health personnel. We could demonstrate the feasibility to routinely apply the EWS in order to repeatedly assess the severity of COVID-19 disease. The EWS is easily calculated in clinical practice within a short period of time with non-invasive measures (Supplementary Table 1). Assessment of the EWS at hospital admission was prognostic for clinical outcome in this COVID-19-positive long-term care facility cohort (Fig. 6); therefore, we recommend applying the EWS in hospitalized COVID-19-positive patients as well as in long-term care facilities in order to objectify disease severity and to prompt countermeasures.

The main limitation of our analysis is the limited number of 50 long-term care facility residents; therefore, conclusions from our findings have to be drawn with caution. Our proposed monitoring and therapeutic measures were associated with a low mortality rate among pre-symptomatic residents; however, a definitive causal role of these measures cannot be derived from our data. Certainly, the rollout of the COVID-19 vaccination strategies might contribute to a significant change in the prognosis and management of this vulnerable population. However, the successful vaccination of a large proportion of people around the world may face significant hurdles and take substantial time periods for which the problem addressed will persist at least in part.

\section{Conclusions}

Case fatality rates among hospitalized long-term care facility residents were mainly derived from symptomatic residents at hospital admission. Deterioration or new onset of fatigue, confusion or fever, and laboratory signs of hyperinflammation, dehydration, or even renal failure were associated with an increased likelihood of COVID-19-associated death and therefore should prompt immediate hospitalization in this vulnerable cohort. Pre-symptomatic residents who developed symptoms during the hospital stay showed a comparably 
good clinical outcome as residents who remained asymptomatic during the course of disease. Based on the latter findings, we suggest the supply of comparable intensity and quality of monitoring and care for asymptomatic and pre-symptomatic COVID-19-positive longterm care facility residents in-house aiming at saving hospital resources.

Supplementary Information The online version contains supplementary material available at https://doi.org/10.1007/s11357021-00352-y.

Author contribution AE, RG, GR, and FH designed the concept of the retrospective analysis. HO and IK performed SARSCoV-2 PCR tests and interpreted PCR results. FH, BJ, and GR collected the data. AE, RG, GR, FH, PM, SF, BS, and EP did the literature research. FH, GR, AE, and RG analyzed and interpreted the results. GR designed the figures. FH and GR wrote the manuscript equally. AE and RG supervised this work. FH, GR, BJ, $\mathrm{PM}, \mathrm{BS}, \mathrm{EP}, \mathrm{SF}, \mathrm{HO}, \mathrm{IK}, \mathrm{RG}$, and $\mathrm{AE}$ read and reviewed the manuscript. All authors approved the final version of the manuscript.

Availability of data and material Data are available from the corresponding author on reasonable request.

Code availability Not applicable

\section{Declarations}

Conflict of interest FH reports travel support from Roche. RG reports honoraria from Celgene, Roche, Merck, Takeda, AstraZeneca, Novartis, Amgen, BMS, MSD, Sandoz, Abbvie, Gilead, and Daiichi Sankyo; consulting for Celgene, Roche, Merck, Takeda, AstraZeneca, Novartis, BMS, MSD, Abbvie, Gilead, Daiichi Sankyo, and Janssen; research funding from Celgene, Roche, Merck, Takeda, AstraZeneca, Novartis, Amgen, BMS, MSD, Sandoz, Gilead, Daiichi Sankyo; travel support from Celgene, Roche, AstraZeneca, Novartis, Amgen, BMS, MSD, Abbvie, Gilead, and Janssen. AE reports consulting and honoraria from Roche. All other authors declare no competing interests.

\section{References}

1. Zhu N, et al. A Novel Coronavirus from patients with pneumonia in China, 2019. N Engl J Med. 2020;382(8): 727-33.

2. Guan WJ, et al. Clinical characteristics of coronavirus disease 2019 in China. N Engl J Med. 2020;382(18):1708-20.
3. Ladhani SN, et al., Investigation of SARS-CoV-2 outbreaks in six care homes in London, April 2020. EClinicalMedicine. 2020;p. 100533.

4. Arons MM, et al. Presymptomatic SARS-CoV-2 infections and transmission in a skilled nursing facility. N Engl J Med. 2020;382(22):2081-90.

5. McMichael TM, et al. Epidemiology of Covid-19 in a longterm care facility in King County. Washington. N Engl J Med. 2020;382(21):2005-11.

6. Burton JK, et al. Evolution and effects of COVID-19 outbreaks in care homes: a population analysis in 189 care homes in one geographical region of the UK. The Lancet Healthy Longevity. 2020;1(1):e21-31.

7. COVID-19 Daily Deaths (NHS England). 2020; Available from: https://www.england.nhs.uk/statistics/statisticalwork-areas/covid-19-daily-deaths/

8. Centers for Disease Control and Prevention. Preparing for COVID-19 in nursing homes. 2020; Available from: https://www.cdc.gov/coronavirus/2019-ncov/hcp/longterm-care.html.

9. Polack FP, et al. Safety and Efficacy of the BNT162b2 mRNA Covid-19 Vaccine. N Engl J Med. 2020;383(27): 2603-15.

10. Voysey M, et al. Safety and efficacy of the ChAdOx1 nCoV-19 vaccine (AZD1222) against SARS-CoV-2: an interim analysis of four randomised controlled trials in Brazil, South Africa, and the UK. Lancet. 2021;397(10269):99-111.

11. Baden LR, et al. Efficacy and safety of the mRNA-1273 SARS-CoV-2 vaccine. N Engl J Med. 2021;384(5):403-16.

12. Makoni M. South Africa responds to new SARS-CoV-2 variant. Lancet. 2021;397(10271):267.

13. Kirby T. New variant of SARS-CoV-2 in UK causes surge of COVID-19. Lancet Respir Med. 2021;9(2):e20-1.

14. Toovey OTR, et al., Introduction of Brazilian SARS-CoV-2 484K.V2 related variants into the UK. J Infect. 2021.

15. Robert Koch Institut. COVID-19: Entlassungskriterien aus der Isolierung, Orientierungshilfe für Ärztinnen und Ärzte. 2020; Available from: https://ww w r i . $\mathrm{de} / \mathrm{DE} / \mathrm{C}$ ontent/Inf A Z / N / N e u artiges Coronavirus/Entlassmanagement-Infografik.pdf?_ blob= publicationFile

16. Royal College of Physicians. (2012). National Early Warning Score (NEWS) standardising the assessment of acute-illness severity in the NHS. London: Royal College of Physicians. 07 October 2020]; Available from: https://www.google.at/url? sa $=$ t\&rct $=$ j\&q $=\&$ esrc $=$ s $\&$ s o u r c e $=$ w e b $\&$ c d $=\&$ v e d $=2$ a h U K E w i a 5 bfUgKLsAhXNzYUKHd5VA5YQFjACegQIAhAC\&url= https $\% 3 \mathrm{~A} \% 2 \mathrm{~F} \% 2 \mathrm{Fwww}$. rcplondon.ac.uk\%2Ffile $\% 2 \mathrm{~F} 32$ $\% 2$ Fdownload\%3Ftoken\%3 DvfwDKQVS\&usg= AOvVaw2wUmhJqFsVxXnotYDW_OSM.

17. EuroMomo - Excess mortality. 2020; Available from: https://www.euromomo.eu/graphs-and-maps/

18. Patel MC, et al. Asymptomatic SARS-CoV-2 Infection and COVID-19 mortality during an outbreak investigation in a skilled nursing facility. Clin Infect Dis. 2020;71(11):2920 6.

19. Tang N, et al. Abnormal coagulation parameters are associated with poor prognosis in patients with novel coronavirus pneumonia. J Thromb Haemost. 2020;18(4):844-7. 
20. Thachil J, et al. ISTH interim guidance on recognition and management of coagulopathy in COVID-19. J Thromb Haemost. 2020;18(5):1023-6.

21. Lechner M, et al. Anosmia and hyposmia in health-care workers with undiagnosed SARS-CoV-2 infection. Lancet Microbe. 2020;1(4):e150.

22. Kennedy M, et al. Delirium in older patients with cOVID-19 presenting to the emergency department. JAMA Netw Open. 2020;3(11):e2029540.

23. Thomas $\mathrm{T}$, et al. COVID-19 infection alters kynurenine and fatty acid metabolism, correlating with IL-6 levels and renal status. JCI Insight. 2020;5:14.

24. Goldman JD, et al. Remdesivir for 5 or 10 days in patients with severe Covid-19. N Engl J Med. 2020.

25. Beigel JH, et al. Remdesivir for the treatment of Covid-19 preliminary report. N Engl J Med. 2020.

26. Consortium WHOST, et al. Repurposed antiviral drugs for Covid-19 - interim WHO solidarity trial results. N Engl J Med. 2020.

27. Group, RC, et al. Dexamethasone in hospitalized patients with Covid-19 - preliminary report. N Engl J Med. 2020.

28. Xu X, et al. Effective treatment of severe COVID-19 patients with tocilizumab. Proc Natl Acad Sci U S A. 2020;117(20): 10970-5.

29. Roche's phase III EMPACTA study showed Actemra/ RoActemra reduced the likelihood of needing mechanical ventilation in hospitalised patients with COVID-19 associated pneumonia. 2020; Available from: https://www.roche. com/investors/updates/inv-update-2020-09-18.htm

30. Stone JH, et al. Efficacy of tocilizumab in patients hospitalized with Covid-19. N Engl J Med. 2020.

31. Hermine O, et al., Effect of tocilizumab vs usual care in adults hospitalized with COVID-19 and moderate or severe pneumonia: a randomized clinical trial. JAMA Intern Med. 2020.

32. Salvarani C, et al., Effect of tocilizumab vs standard care on clinical worsening in patients hospitalized with COVID-19 pneumonia: a randomized clinical trial. JAMA Intern Med, 2020.

33. Roche provides an update on the phase III COVACTA trial of Actemra/RoActemra in hospitalised patients with severe COVID-19 associated pneumonia. 2020; Available from: https://www.roche.com/investors/updates/inv-update-202007-29.htm.

34. Tocilizumab reduces deaths in patients hospitalised with COVID-19. 2021; Available from: https://www. recoverytrial.net/news/tocilizumab-reduces-deaths-inpatients-hospitalised-with-covid-19.

35. Mehra MR, et al. Cardiovascular disease, drug therapy, and mortality in Covid-19. N Engl J Med. 2020;382(25):e102.

36. Zhou F, et al. Clinical course and risk factors for mortality of adult inpatients with COVID-19 in Wuhan, China: a retrospective cohort study. Lancet. 2020;395(10229):1054-62.

37. Gutierrez-Gonzalez E, et al. Effect of vaccination, comorbidities and age on mortality and severe disease associated with influenza during the season 2016-2017 in a Spanish tertiary hospital. J Infect Public Health. 2019;12(4):486-91.

38. Moreh E, Jacobs JM, Stessman J. Fatigue, function, and mortality in older adults. J Gerontol A Biol Sci Med Sci. 2010;65(8):887-95.

39. Hoffmann M, et al. SARS-CoV-2 cell entry depends on ACE2 and TMPRSS2 and is blocked by a clinically proven protease inhibitor. Cell. 2020;181(2):271-80 e8.

40. Ferrario CM, et al. Effect of angiotensin-converting enzyme inhibition and angiotensin II receptor blockers on cardiac angiotensin-converting enzyme 2. Circulation. 2005;111(20):2605-10.

41. Reynolds HR, et al. Renin-Angiotensin-Aldosterone System Inhibitors and Risk of Covid-19. N Engl J Med. 2020;382(25):2441-8.

42. Lopes RD.et al., Continuing versus suspending angiotensinconverting enzyme inhibitors and angiotensin receptor blockers: impact on adverse outcomes in hospitalized patients with severe acute respiratory distress syndrome coronavirus 2 (SARS-CoV-2): the BRACE CORONA trial. Presented at: ESC Congress 2020. September 1, 2020

43. Lee SW, et al. Severe clinical outcomes of COVID-19 associated with proton pump inhibitors: a nationwide cohort study with propensity score matching. Gut. 2020.

44. Tremblay D, et al. Impact of anticoagulation prior to COVID-19 infection: a propensity score-matched cohort study. Blood. 2020;136(1):144-7.

45. Schloer S, et al. Targeting the endolysosomal host-SARS$\mathrm{CoV}-2$ interface by clinically licensed functional inhibitors of acid sphingomyelinase (FIASMA) including the antidepressant fluoxetine. Emerg Microbes Infect. 2020;9(1): 2245-55.

Publisher's note Springer Nature remains neutral with regard to jurisdictional claims in published maps and institutional affiliations. 